\title{
IMPROVING HUMAN RESOURCES PERFORMANCE AND JOB SATISFACTION THROUGH TRANSACTIONAL LEADERSHIP AND INTRINSIC MOTIVATION
}

\author{
Wuryanti $^{1 *}$, Aldan Rifki Rismawan ${ }^{2}$ \\ *Corresponding Author \\ ${ }^{1}$ Dept. of Management, Faculty of Economics, Universitas Islam Sultan Agung,Indonesia, Jalan Raya Kaligawe KM 4 \\ Semarang, Indonesia \\ wuryanti@unissula.ac.id \\ ${ }^{2}$ Undergraduate Student at Dept. of Management, Faculty of Economics, Universitas Islam Sultan Agung,Indonesia, Jalan \\ Raya Kaligawe KM 4 Semarang, Indonesia \\ aldan.rismawan04@gmail.com
}

\begin{abstract}
This study aims to determine and analyze the effect of transactional leadership and intrinsic motivation on HR performance, with job satisfaction as an intervening variable. This study used primary data obtained from questionnaires. The populations in this study were 155 employees of PT. SCM Enterprises Apparel who works in the production department. The research sample was 112 respondents with the cluster random sampling as a method. The results showed that transactional leadership had a positive and significant effect on HR performance, intrinsic motivation had a positive and significant effect on HR performance, job satisfaction had a positive and significant effect on HR performance, transactional leadership had a positive and significant effect on job satisfaction, intrinsic motivation had a positive and significant effect on job satisfaction, and job satisfaction cannot mediate the effect of transactional leadership and intrinsic motivation on HR performance.
\end{abstract}

Keywords: Transactional leadership, intrinsic motivation, job satisfaction, hr performance

Received

February 26, 2020

\section{Revised}

March 31, 2020

\section{Accepted}

March 31, 2020
Published

March 31, 2020

\section{INTRODUCTION}

In the era of globalization, competition between companies to compete with others is getting tougher. This causes companies not only faced with domestic competition but also abroad. A company can achieve the goals set depending on the contribution of various elements in the company (Sudarmanto, 2009). This contribution can be in the form of planning, organizing, directing, coordinating and supervising.

The behavior of human resources individually and in groups can have a considerable impact on company performance. This requires companies to be able to think about how to manage the existing human resources in the company to work optimally to achieve company goals. The increase in company performance is influenced by several factors including the performance of existing human resources in the company, but not many companies are willing to spend enough to be able to improve HR performance in the company.

Evaluation for HR performance is very important to be done by the company as a benchmark in making decisions and policies for companies and make the human resources in the company encouraged to improve their performance so as to achieve the goals set by the company (Rivai, 2005). According to Rahmat (2008), HR performance can be influenced by several factors, which are leadership, motivation, work environment, and job satisfaction.

According to Bass (2003), an important factor that determines HR performance and the ability of organizations to adapt to the environment is transactional leadership, which means a leader is more focused on the process of exchange between leaders and subordinates or 
between human resources in the company. Another factor is intrinsic motivation. Cong and Van (2013) define intrinsic motivation as motivation that encourages human resources to excel and improves performance, in this case, the impetus comes from each human resource in order to achieve predetermined company goals.

According to Robbins (2007), there is other variable that can affect the HR performance, namely job satisfaction variable, which means a pleasant or unpleasant emotional attitude or feeling that is felt or indicated by human resources from what the company gives to him. This can be seen from whether the rewards received by human resources are appropriate or not as expected.

There are differences in research results regarding the influence of transactional leadership and intrinsic motivation on HR performance. James Tallitu (2014) and Taufan Pradana (2016) found that transactional leadership has an effect on HR performance, whereas Eko Yudhi Setiawan (2015) and A Nur Ihsan (2017) found that transactional leadership has no effect on HR performance.

Fatohu Waruwu (2017) and Indra Surya Permana (2016) found that intrinsic motivation affects HR performance, while Budianto (2013) and Linawati (2014) found that intrinsic motivation does not affect HR performance.

PT. SCM Enterprises Apparel is one of the companies in Semarang which is engaged in the textile industry, whereas a company engaged in the field, of course, will have many competitors in their own area and other cities around Semarang. Therefore, the role of HR performance is very important to achieve the company's goals.

Based on the background of the study above, the research question in this study is as follows:

1. How does Transactional Leadership influence HR Performance?

2. How does Intrinsic Motivation influence HR Performance?

3. How does Job Satisfaction influence HR Performance?

4. How does Transactional Leadership influence Job Satisfaction?

5. How does Intrinsic Motivation influence Job Satisfaction?

\section{LITERATURE REVIEW}

\section{Transactional Leadership}

Transactional leadership is a style of leadership that focuses on the process of exchange between leaders and subordinates, in this case, a leader provides rewards in accordance with HR performance in the company. This is in line with the statement of Robbins and Coulter (2010) that transactional leadership becomes a social exchange transaction carried out by a leader by giving guidance and motivation to his subordinates in order to achieve goals and also provide rewards and bonuses for the performance shown by these subordinates. Whereas Bass (2017) defines transactional leadership as a leadership style where a person influences and motivates his subordinates by giving rewards with certain performance standards. In a transaction, a subordinate is given a reward in accordance with the work done based on agreement. Metcalfe, (2016) argues that transactional leadership must be able to know what is needed and desired in accordance with the results of assignments charged to subordinates. 
If a leader can find out what is desired by human resources in his company, this can facilitate the leader in improving HR performance in the company.

According to Antonakis and House (2002), transactional leadership is leadership in which a leader explains to employees about the assignment to be carried out and communicates well about how to complete tasks in accordance with the desires of the leader. Yukl (2010) suggests that transactional leadership is a leadership that involves the exchange values between leaders and subordinates and motivates HR by using their personal interests to work optimally.

Based on the explanation above, it can be concluded that HR performance is a result of a comparison between work results and the workload. There are many factors that can affect HR performance internally and externally. Therefore, the researchers want to know even more other factors that can affect HR performance in the company.

As for some transactional leadership indicators according to Bass and Riggio (2006), are: (1) Contingent Rewards, (2) Exception Management, and (3) Trust.

\section{Intrinsic Motivation}

Nawawi (2015) defines intrinsic motivation as an encouragement that comes from within a particular individual that encourages to work more optimally. Whereas Handoko (2017) defines intrinsic motivation as a motivation that functions without stimulation from outside the individual but comes from within an individual who has the drive to carry out the work based on workload.

According to George and Jones (2005), an employee who has high intrinsic motivation tends to challenge himself to continue to pursue achievements, achieve all the potential that can be achieved, and contribute to the company. According to Herzberg (2017), Intrinsic motivation is a stimulus originating from within an individual that influences to work better to achieve organizational goals.

Based on the explanation above, it can be concluded that intrinsic motivation is a motivation that encourages individuals to continue to improve their performance within the company through each individual himself without any stimulation from outside the individual.

As for some indicators of intrinsic motivation according to Herzberg (2006) are: (1) enthusiasm at work, (2) Awards, (3) Work itself, (4) Responsibilities, and (5) Development.

\section{Job Satisfaction}

According to Hasibuan (2015), job satisfaction is an emotional feeling that is fun and loves work by employees as indicated by work morals, discipline, and work performance. Meanwhile, according to Staw (2016), job satisfaction is the attitude of an individual towards his work based on the experience and benefits of the work he is running.

Pennington and Riley, (2015) define job satisfaction as an internal or external value of an individual for work performed based on how satisfied the individual is with a standard set by the company. Meanwhile, according to sulistiyani (2016), job satisfaction is a comparison between what is provided by the company and what is expected by the individual. This is focused on the reciprocity given by the company over how much contribution has been given. Therefore, it can be concluded that job satisfaction is a pleasant emotional feeling that is 
shown by human resources in the company based on what is received from the company in accordance with what is expected.

As for several indicators of job satisfaction according to Hasibuan (2015) are: (1) Sense of Pride towards the Company, (2) Enjoying and Loving Work, and (3) Work environment.

\section{HR Performance}

HR performance, according to Riani (2011), is a quality work result produced by a person towards the assignment and responsibilities given to him. Meanwhile, according to Hasibuan (2012), HR performance is a result of work achieved by a person from a given workload based on skills, time, and experience.

Arifin (2012) defines the performance of human resources as a result of work achieved by someone based on certain criteria used in certain companies in their valuation standards. Meanwhile, according to Abdullah (2014), HR performance is the result of work achievement achieved by employees in an organization. The greater the results of work performance, the higher the HR performance will be.

Based on the description above, it can be concluded that HR performance is a result of a comparison between a work result and workload. Many factors can affect the performance of human resources in the company both from internal and external factors that make researchers want to know even more other factors that can affect HR performance in the company. As for several indicators of HR performance according to Mathis and Jackson (2014) are: (1) Quality of work, (2) Quantity of work (3) Timeliness, (4) Absenteeism and (5) Knowledge.

\section{HYPOTHESES}

H1: Transactional leadership influences HR performance.

$\mathrm{H} 2$ : Intrinsic motivation influences HR Performance

H3: Job Satisfaction influences HR Performance

H4: Transaction leadership influences job satisfaction.

H5: Intrinsic Motivation influences Job Satisfaction.

\section{Empirical Research Model}

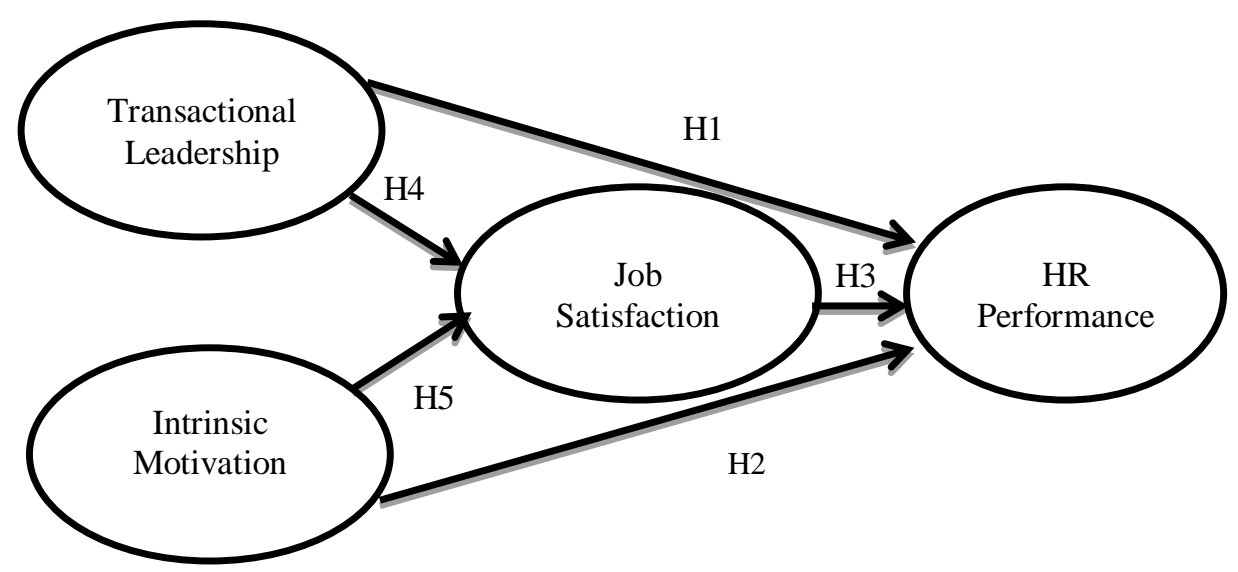

Figure 1. Empirical Model 


\section{RESEARCH METHODOLOGY}

\section{Population and Sample}

The population is a generalization area consisting of subjects and objects that have certain characteristics that are determined by researchers and then drawn a conclusion (Sugiyono 2012). The populations in this study are 155 employees in the production department who work at PT. SCM Enterprises Apparel.

The sample is a portion of the population whose characteristics are to be investigated, which is then considered to be representative of the entire population. Based on the size of the population, it is necessary to take a limitation for a sample. To provide accurate results, the number of samples taken is sought by using the Slovin formula (Umar, 2012). The formula for determining the number of samples used is as follows:

$$
\frac{\mathrm{n}=\mathrm{N}}{1+N \mathrm{e}^{2}}
$$

Based on the calculation above by using a sampling rate that can still be tolerated (5\%), it is obtained that the number of samples is 112 respondents in the production department employees at PT. SCM Enterprises Apparel. The sampling technique in this study is Cluster Random Sampling which means a sampling technique whose sample selection refers to groups, not to individuals. Cluster Random Sampling is an area sampling technique used to determine samples if the object used in research or its data source is very broad (Sugiyono, 2012). The sampling technique is as follows:

Table 1. Sampling technique

\begin{tabular}{lccc}
\hline \multicolumn{1}{c}{ Department } & Population & Proportional & Samples taken \\
\hline Cutting & 30 & $\frac{30}{155} \times 112=22,4$ & 22 \\
\hline Operator Sewing & 40 & $\frac{40}{155} \times 112=28,9$ & 29 \\
\hline Helper Sewing & 28 & $\frac{28}{155} \times 112=20,2$ & 20 \\
\hline Finishing & 32 & $\frac{32}{155} \times 112=23,1$ & 23 \\
\hline Packing & 25 & $\frac{25}{155} \times 112=18,1$ & 18 \\
\hline Total Respondents & 155 & & 112 \\
\hline
\end{tabular}

\section{Data analysis method}

The data analysis method is done by using a quantitative analysis test using a path analysis tool, where previously the validity and reliability tests were performed as well as the classical assumption requirements test. The regression equation is as follows:

$$
\begin{gathered}
\mathrm{Y} 1=\mathrm{a}+\beta 1 \mathrm{X} 1+\beta 2 \mathrm{X} 2+\mathrm{e} \\
\mathrm{Y} 2=\mathrm{a}+\beta 1 \mathrm{X} 1+\beta 2 \mathrm{X} 2+\beta 3 \mathrm{Y} 1+\mathrm{e}
\end{gathered}
$$

Where:

Y1 : Job satisfaction

Y2 : HR performance

$\mathrm{X} 1$ : Compensation

$\mathrm{X} 2$ : Islamic Work Ethic

$\mathrm{B}_{1,2,3}$ : Coefficient of Multiple Regression 
e : error

a : Constant

\section{RESULTS}

Instrument Test

\section{a. Validity Test}

A validity test is used to determine whether a questionnaire can be said to be valid or not. Also, it is used to measure or express the question items in the questionnaire (Ghozali, 2012). The level of validity can be measured by comparing the value of $r$-count (correct item of total correlation) with the value of $r$-table, where if the value of $r$-count $>r$-table, then the statement is said to be valid, whereas if the value of r-count $<r$-table, meaning that the statement is said to be invalid.

Table 2. Validity Test

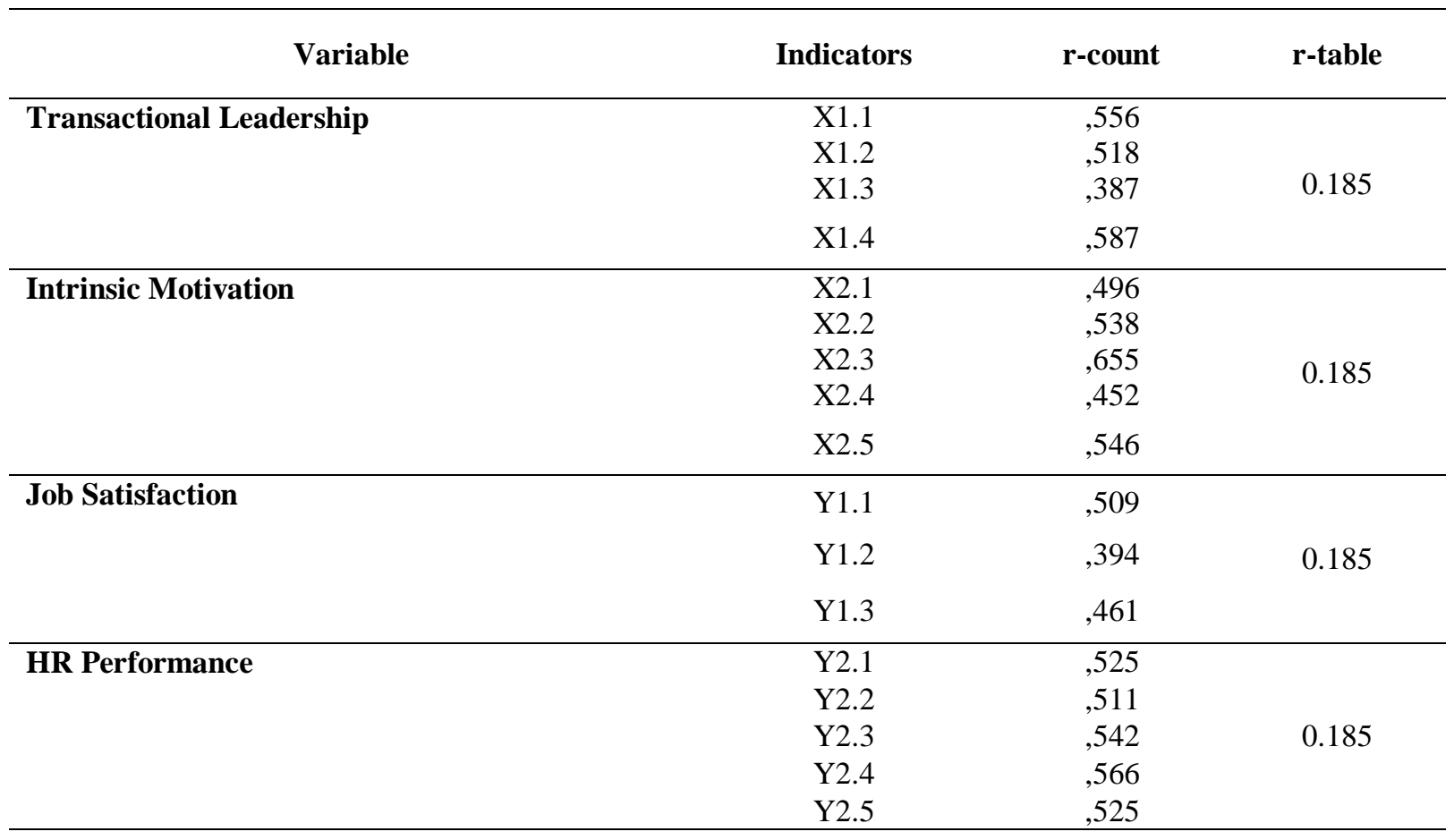

Based on table 2, it can be seen that the value of r-count> r-table is (0.185), it can be concluded that all indicators of each variable used in this study (transactional leadership, intrinsic motivation, job satisfaction, and HR performance) is valid.

\section{b. Reliability Test}

Reliability test is used to measure the questionnaire which becomes a construct indicator. A questionnaire can be said to be reliable if the answers of the questionnaire are stable and consistent (Ghozali, 2012). 
Table 3. Reliability Test Results

\begin{tabular}{c|c}
\hline \multicolumn{2}{c}{ Reliability Statistics } \\
\hline Cronbach's Alpha & N of Items \\
\hline 0.827 & 17 \\
\hline
\end{tabular}

Based on the results of reliability testing with SPSS, it is obtained Cronbach's Alpha value of $0.827>0.60$ which means that all questions used in this study have met the requirements and can be said to be reliable.

\section{Classical Assumption Test}

Before a regression test is performed, the classical assumption test is performed first.

\section{a. Normality Test}

Table 4. Normality Test Results

\begin{tabular}{|c|c|}
\hline \multicolumn{2}{|c|}{ One-Sample Kolmogorov-Smirnov Test } \\
\hline Model & Asymp. Sig. (2-tailed) \\
\hline 1 & 0,770 \\
\hline 2 & 0,963 \\
\hline
\end{tabular}

Based on the results of the Kolmogorov-Smirnov test in Table 4 Model 1, the HR performance variable as the dependent variable is known that the value of Asymp. sig (2tailed) of $0.770>0.05$, the research data of transactional leadership, intrinsic motivation, and job satisfaction on HR performance are stated normally distributed. While in model 2, namely job satisfaction as the dependent variable is known that the value of Asymp. Sig (2tailed) of $0.963>0.05$, the research data of transactional leadership variable and intrinsic motivation on job satisfaction are normally distributed so that this research is fit.

\section{b. Multicollinearity Test}

Table 5. Multicollinearity Test

\begin{tabular}{lll}
\multirow{2}{*}{ Model } & \multicolumn{2}{c}{ Collinearity Statistics } \\
\cline { 2 - 3 } & Tolerance & VIF \\
\hline (Constant) & & \\
\hline $\begin{array}{l}\text { Transactional } \\
\text { Leadership }\end{array}$ & 0.550 & 1.817 \\
\hline Intrinsic Motivation & 0.584 & 1.713 \\
\hline Job Satisfaction & 0.402 & 2.490
\end{tabular}


The results of multicollinearity test in table 5 show that the tolerance value of each variable is greater than the default value specified at 0.10 while the VIF (Variance Inflation Factor) value also shows below the number 10. In conclusion, all variables used in research have met the requirements of tolerance threshold and VIF value, meaning that there is no correlation between the independent variables used in the study.

\section{c. Heteroscedasticity Test}

Table 6. Heteroscedasticity Test

\begin{tabular}{ll}
\hline Model & Sig. \\
\hline (Constant) & \\
Transactional Leadership & 0.303 \\
Intrinsic Motivation & 0.130 \\
Job Satisfaction & 0.900 \\
\hline
\end{tabular}

Based on table 6, it is known that the four variables used in the study (transactional leadership, intrinsic motivation, and job satisfaction) has significant values $>0.05$ so that it can be concluded that there is no heteroscedasticity problem in the regression model, meaning that it is feasible to be used to predict transactional leadership, intrinsic motivation, and job satisfaction on HR performance.

\section{Multiple Linear Regression Test}

\begin{tabular}{lcccc}
\multicolumn{1}{c}{ Table 7. Summary of Regression Equations } \\
\hline Variables & B & T count & Sig & Conclusion \\
& & & & \\
\hline $\mathrm{X} 1 \rightarrow \mathrm{Y} 2$ & 0,342 & 4,665 & 0,000 & Ha accepted \\
$\mathrm{X} 2 \rightarrow \mathrm{Y} 2$ & 0,368 & 5,168 & 0,000 & Ha accepted \\
$\mathrm{Y} 1 \rightarrow \mathrm{Y} 2$ & 0,264 & 3,082 & 0,003 & Ha accepted \\
$\mathrm{X} 1 \rightarrow \mathrm{Y} 2$ & 0,477 & 7,037 & 0,000 & Ha accepted \\
$\mathrm{X} 2 \rightarrow \mathrm{Y} 1$ & 0,432 & 6,363 & 0,000 & Ha accepted \\
\hline
\end{tabular}

\section{HYPOTHESIS TESTING}

\section{Effect of Transactional Leadership on HR Performance}

The results of the transactional leadership variable (X1) based on table 8 above, it was obtained the value of $\mathrm{t}$-count $=4.665$ by using a significance level of $5 \%$ and the value of $\mathrm{t}$ table of 1.659 which means the calculated value shows that $\mathrm{t}$-count $>\mathrm{t}$ - the table is $4,665>$ 1,659. That is, there is a positive and significant effect of transactional leadership on HR performance.

While based on the significance value, it is obtained sig. value of $=0,000<$ significance level of $5 \%$ or 0.05 , meaning that there is a positive and significant influence of the transactional leadership variable on HR performance variable. Thus, the hypothesis stating that the transactional leadership influences the HR performance is accepted. 


\section{Effect of Intrinsic Motivation on HR Performance}

The results of intrinsic motivation based on table 8 above, it was obtained the value of $t$ arithmetic $=5.168$ by using a significance level of $5 \%$ and t-table value of 1.659 which means the calculated results show that $\mathrm{t}$-count $>\mathrm{t}$-table is $5.168>1.659$. That is, there is a positive and significant effect between intrinsic motivation on HR performance.

While based on the significance value, it is obtained sig. value $=0,000<$ significance level of $5 \%$ or 0.05 means that there is a positive and significant influence of intrinsic motivation on HR performance. Thus, the hypothesis stating that the intrinsic motivation influences the HR performance is accepted.

\section{Effect of Job Satisfaction on HR Performance}

The results of job satisfaction based on table 8 above, it was obtained the value of $t$ count $=3.082$ using a significance level of $5 \%$ and t-table value of 1.659 which means the calculated results show that $\mathrm{t}$-count $>\mathrm{t}$-table is $3.082>1.659$. That is, there is a positive and significant effect of job satisfaction on HR performance.

While based on the significance value, it was obtained a sig value of $=0.003<$ significance level of $5 \%$ or 0.05 , meaning that there is a positive and significant influence of job satisfaction on HR performance. Thus, the hypothesis stating that the job satisfaction influences HR performance is accepted.

\section{Effect of Transactional Leadership on Job Satisfaction}

The results of transactional leadership obtained $\mathrm{t}$-value $=7.037$ by using a significance level of $5 \%$ and t-table value of 1.659 which means the calculated value shows that $t$-count> t-table is 7.037> 1.659. That is, there is a positive and significant effect of transactional leadership on job satisfaction.

While based on the significance value, it is obtained sig value $=0,000<$ significance level of $5 \%$ or 0.05 means that there is a positive and significant influence between the transactional leadership on job satisfaction. Thus, the hypothesis stating that the transactional leadership influences job satisfaction is accepted.

\section{Effect of Intrinsic Motivation on Job Satisfaction}

The result of intrinsic motivation is obtained $t$-count $=6,363$ by using a significance level of $5 \%$ and t-table value of 1,659 which means the calculated value shows that $t$-count $>\mathrm{t}$-table is $6.363>1.659$. That is, there is a positive and significant effect of intrinsic motivation on job satisfaction.

While based on the significance value, it was obtained a sig value of $=0,000<$ significance level of $5 \%$ or 0.05 , meaning that there is a positive and significant influence between the intrinsic motivation on job satisfaction. Thus, the hypothesis that the intrinsic motivation influences the job satisfaction is accepted.

\section{Coefficient of Determination}

Table 8. Coefficient of Determination

\begin{tabular}{c|c|c|c}
\hline Model & R & R Square & $\begin{array}{c}\text { Adjusted R } \\
\text { Square }\end{array}$ \\
\hline
\end{tabular}




\begin{tabular}{llll}
\hline 1 & 0,744 & 0,598 & 0,591 \\
\cline { 4 - 4 } \cline { 4 - 4 } 2 & 0,825 & 0,681 & 0,672 \\
\hline
\end{tabular}

Based on the test results, it can be shown that the value of Adj. $\mathrm{R}^{2}$ in the model 1 is obtained at 0.591 , which means that $59.1 \%$ of transactional leadership and intrinsic motivation can explain the Job Satisfaction of employees working in the production department at PT. SCM Enterprises Apparel was 59.1 percent, and the remaining 40.9 percent was explained by other factors not examined.

Adj. Value R2 in the path 2 models is obtained at 0.672 which shows that transactional leadership, intrinsic motivation, and job satisfaction can explain HR performance of 67.2 percent, while the remaining 32.8 percent is explained by other factors.

\section{Path Analysis Test Results}

Table 9. Path Analysis Test Results

\begin{tabular}{c|l|c}
\hline Independent & Direct and Indirect Effects & B \\
\hline \multirow{2}{*}{ Transactional Leadership } & Direct Influence & 0,342 \\
& Indirect Effects & 0,126 \\
\hline \multirow{2}{*}{ Intrinsic Motivation } & Direct Influence & 0,368 \\
& Indirect Effects & 0,114 \\
\hline
\end{tabular}

Based on the results of the path analysis test in table 9 on the direct influence of transactional leadership on HR performance, a value of 0.342 is obtained, while the indirect effect through job satisfaction is 0.126 , it shows that the direct effect of transactional leadership is greater than the indirect effect through job satisfaction. Thus, job satisfaction cannot mediate the effect of transactional leadership on HR performance.

Whereas the direct effect of intrinsic motivation on HR performance is 0.368 while the indirect effect through job satisfaction is 0.114 , it shows that the direct effect of intrinsic motivation is greater than the indirect effect through job satisfaction. Thus, job satisfaction cannot mediate the influence of motivation intrinsic to HR performance.

\section{Sobel Test Results}

Table 10. Sobel Test Results

\begin{tabular}{lcc|c}
\hline Explanation & $\begin{array}{c}\text { Sobel Test } \\
\text { Statistic }\end{array}$ & $\begin{array}{c}\text { One Tailed } \\
\text { Probability }\end{array}$ & Two Tailed Probability \\
\hline $\begin{array}{l}\text { Transactional Leadership> Job Satisfaction } \\
\text { Job Satisfaction> HR Performance }\end{array}$ & 1,7031 & 0,0442 & 0,0885 \\
\hline $\begin{array}{l}\text { Intrinsic Motivation> Job Satisfaction } \\
\text { Job Satisfaction> HR Performance }\end{array}$ & 1,7059 & 0,0440 & 0,0880 \\
\hline
\end{tabular}

Based on the sobel test results in the table above, it can be seen that the influence of transactional leadership on HR performance through job satisfaction produces a probability 
value of 0.0885 , because probability values $>0.05$ so that $\mathrm{Ha}$ is accepted, It concludes that job satisfaction cannot mediate the effect of transactional leadership on HR performance.

Based on the Sobel test results, it is known that the effect of intrinsic motivation on HR performance through job satisfaction produces a probability value of 0.0880 , because probability values $>0.05$ then $\mathrm{Ha}$ is accepted. It means, job satisfaction cannot mediate the effect of intrinsic motivation on HR performance.

\section{DISCUSSION}

\section{Effect of Transactional Leadership on HR Performance}

The results showed that transactional leadership had a positive and significant effect on HR performance. It means, if the transactional leadership is implemented well by the company, it will make the HR performance in the company also good. Thus, if passive exception management is improved and implemented well within the company, it will make HR more serious in paying attention and minimizing the level of absenteeism in carrying out work within the company. Meanwhile, if active exception management is improved, it will improve HR performance in the form of quality by completing work properly in accordance with the standards set by the company.

Based on the description above, transactional leadership influences the HR performance in PT. SCM Enterprises Apparel. The results of this study support research conducted by Nur Septi Aqmarina, et al (2016) which shows that transactional leadership influences HR performance. The same thing was stated by Stelina Permata Sari (2017) that the encouragement given by a leader from the exchange or reward process is based on an agreement on clarifying goals, work standards, job assignments, and awards. The more a leader appreciates the work done by HR by providing rewards in accordance with the work carried out, it will make the HR performance better.

\section{Effect of Intrinsic Motivation on HR Performance}

The results showed that intrinsic motivation had a positive and significant effect on HR performance. This means that the higher (better) the intrinsic motivation within HR, the better HR performance within the company. Thus, the higher the enthusiasm for work owned by HR in the company, it will make HR to pay more attention to the level of absence in the company. Whereas if HR strives to always increase the level of potential development it has, it will make HR timelier to come to work. The higher the sense of responsibility that HR has in completing work, it will be able to improve the quality of the HR in carrying out work charged to him in accordance with the variations set by the company. If the work carried out by the HR in the company is in accordance with the expertise possessed by HR, it will increase the ability of HR to complete the work that is charged properly in accordance with the time determined by the company.

Based on the description above, intrinsic motivation influences HR performance. This supports the research conducted by Ahmad Taufiq (2016) who found that intrinsic motivation influences HR performance in the company. The same was stated by A Nur Insan (2017), intrinsic motivation is reflected in individual behavior in completing a job on time to improve HR performance. This is because completing work on time will make it more productive and 
improve its performance in the company. Indah Raisyah Rianda (2015) also suggested that there is an influence between intrinsic motivation on HR performance.

\section{Effect of Job Satisfaction on HR Performance}

The test results show the results that job satisfaction has a positive and significant effect on HR performance. This means that the higher (better) job satisfaction felt by HR in the company will increase HR performance within the company. Thus, if the feeling of pleasure on work is increased, it will make the HR pay more attention to the level of attendance and try to minimize the level of absence. Whereas, the higher sense of pride of HR on the company, it will make HR more time to come in work, and if the work environment is improved, it will improve the quality of HR in completing the work that is charged to him properly without any mistakes.

Based on the description above, job satisfaction affects HR performance. The results of this study support the research conducted by Indah Raisyah Rianda (2015), which job satisfaction affects HR performance. The same thing was stated by Nanang Setiaji, et al (2016) that HR whose needs have been fulfilled by the company will make the HR more active in carrying out their work so that it will improve HR performance in the company. Ahmad Taufiq (2016) also suggested that there was an influence between job satisfaction on HR performance.

\section{Effect of Transactional Leadership on Job Satisfaction}

The results showed that there was a positive and significant relationship between transactional leadership and job satisfaction. This means that the better transactional leadership is applied within the company, the better the performance of HR in the company. Thus, if the application of passive exception management is improved within the company, it will increase the pleasure of HR in carrying out work in the company. If the trust given by the leader to HR is increased, it will increase the pride of HR towards the company. If active exception management is improved, it will improve the supportive work environment in carrying out work within the company.

Based on the description above, transactional leadership influences job satisfaction. The results of this study support research conducted by Nanang Setiaji, et al (2016) which shows that transactional leadership influences job satisfaction. The same thing was also stated by Nur Septi Aqmarina, et al (2016) who stated that transactional leadership that was implemented well in the company from the trust given by the company to its HR in the company in carrying out the assignments charged was able to create its satisfaction for the HR in carrying out work. Stelina Permata Sari (2014) in her research stated that transactional leadership influences job satisfaction.

\section{Effect of Intrinsic Motivation on Job Satisfaction}

The results showed that there was a positive and significant relationship between intrinsic motivation and job satisfaction. This means that the higher the intrinsic motivation within HR, the better job satisfaction is felt by the HR within the company. Thus, if the enthusiasm of work owned by HR is increased, it will increase the sense of pleasure of HR for work in the company. Meanwhile, if the development of HR potential is increased, HR 
will be proud of the company. If HR increases the sense of responsibility they have, it will improve the work environment which makes the environment more conducive to carrying out work that is charged by the company.

Based on the description above, intrinsic motivation influences job satisfaction. This supports the research conducted by Mukhamad Yasin, et al (2016) that there is an influence between intrinsic motivation on job satisfaction. The more the individual has a high impetus in carrying out the assignments given by the company, then it will be able to increase his job satisfaction. The assignment given by the company is done based on the sense of interest and pleasure that the individual feels in completing the tasks assigned to him. Furthermore, Indah Raisyah Rianda (2015) suggested that intrinsic motivation influences job satisfaction. Ahmad Taufiq (2016) also explained that intrinsic motivation can be influenced by encouragement given by the company to increase responsibility, ability to excel, and get recognition from others for its performance in the company.

\section{Direct and Indirect Effects}

Based on the results of the path analysis test and the sobel test, it can be seen that the direct effect of transactional leadership is obtained at a value of 0.382 and its indirect effect through job satisfaction of 0.126 . This shows that job satisfaction cannot mediate the relationship between transactional leadership and HR performance. This is also supported by the results of the sobel test where the effect of transactional leadership on HR performance through job satisfaction produces a probability value of 0.0885 , because the probability value $>0.05$. This shows that job satisfaction is not able to be an intervening variable between the influence of transactional leadership and HR performance. This can be interpreted that transactional leadership has a greater influence on HR performance, because companies that conduct oversight of HR within the company when the targets set by the company are not able to be achieved and show the company's confidence in the leader towards HR. This makes HR not burdened with evaluations and supervision in the company so that it is more capable of being able to improve HR performance compared to feeling proud of the company.

The results of the path analysis test and the sobel test are known that the direct effect of intrinsic motivation on HR performance obtained a value of 0.368 and its indirect effect through job satisfaction of 0.114 . It shows that the effect of job satisfaction cannot mediate the relationship between intrinsic motivation on HR performance. While the sobel test on the effect of intrinsic motivation on HR performance through job satisfaction produces a probability value of 0.0880 , because the probability value $>0.05$. This shows that job satisfaction is not able to be an intervening variable that can mediate between the influence of intrinsic motivation on HR performance. This can be interpreted that intrinsic motivation has a greater influence on HR performance. Intrinsic motivation in the form of enthusiasm increases the potential and achieves better work performance so that it can encourage HR to be more active and work their best. This has a more dominant influence than pride and pleasure at work. 


\section{CONCLUSION}

Based on research that has been done, the conclusions of this study are first; transactional leadership has a positive and significant effect on HR performance, meaning that transactional leadership can be applied optimally to improve HR performance. This can be seen in management indicators with a passive exception where the leader only takes action when the target set by the company is not achieved. Second; intrinsic motivation has a positive and significant effect on HR performance, meaning that the higher the motivation that exists in HR in the company, the more capable the HR performance will be in the company. This can be seen from the indicator of 'my work makes me passionate at work', where the sense of enthusiasm shown by HR on work makes work faster so that it can improve HR performance.

Third; job satisfaction has a positive and significant effect on HR performance, meaning that the higher the satisfaction felt by HR, it will be able to improve HR performance in the company. This is seen in the indicator of 'feeling happy to the job', where when HR is happy with the work, it will increasingly make the HR work better so that it can improve performance. Fourth; transactional leadership has a positive and significant effect on job satisfaction, meaning that the more optimal leadership is applied in the company, it will be able to increase HR job satisfaction. If the company can provide rewards in accordance with HR performance, it will be able to increase job satisfaction.

Fifth; intrinsic motivation has a positive and significant effect on job satisfaction, meaning that the higher the intrinsic motivation that exists in HR, then it will increase HR work satisfaction. If HR does the work that is charged only for its interests but can do it well it will increase HR work satisfaction. The last; job satisfaction cannot mediate the relationship between transactional leadership on HR performance and intrinsic motivation on HR performance.

\section{SUGGESTION}

Based on the conclusion above, some suggestions can be given and are expected to be useful for improving company performance. Some of these suggestions are:

a. In intrinsic motivation, the indicator of appreciation gets a lower value compared to other indicators. This company should encourage more HR to further improve their achievements in working by promising bonuses and awards for their achievements.

b. In transactional leadership, the contingent reward indicator gets a lower value than the other indicators. This company should give bonuses and rewards to HR who excel or who have good performance in the company.

c. In job satisfaction, work environment indicator gets lower scores than other indicators. This should enable the company to provide work environment facilities that are more supportive of HR in working, such as by maintaining workplace hygiene. 


\section{LIMITATION}

Based on the research that has been done, the limitations in this study are first; the results of testing the goodness of fit that is by looking at the Adjusted R Square model 1 of $59.1 \%$ while the remaining of $40.9 \%$ factors have not been considered in the regression model. This adjusted R-squared value explains why this research has not been maximized and can prove the factors that influence job satisfaction in HR production at PT. SCM Enterprises Apparel. Thus, further research needs to explore other factors that have not yet been studied. Second; based on the limitations above, further research should use independent variables that can affect job satisfaction apart from the variables used in this study. Also, future research is expected to research companies engaged in other fields such as manufacturing, government agencies, and hospitals to obtain better results.

\section{REFERENCES}

Budianto, Ferdinand, \& Sambung, R. (2013). Pengaruh Motivasi Intrinsik dan Motivasi Ekstrinsik Terhadap Kinerja Pegawai Melalui Kepuasan Kerja. Jurnal Sains Manajemen, ISSN : 2302-1411.

Ghozali, I. (2012). Aplikasi Analisis Multivariate dengan Program SPSS 19. Semarang: Badan Penerbit Universitas Diponegoro.

Guritno, B., \& Prabowo, H. (2016). Analisis Pengaruh Motivasi Intrinsik Terhadap Kepuasan Kerja Yang Berdampak Pada Kinerja Karyawan Di PT. Jhons GF Semarang. Buletin Bisnis \& Manajemen, ISSN: 2442-885X.

Hillaliyyah, N. (2016). Pengaruh Kepemimpinan Transaksional Terhadap Kinerja Karyawan. Management Analysis Journal, ISSN 2252-6552.

Ihsan, A. n. (2017). Pengaruh Kepemimpinan Transaksional Dan Motivasi Intrinsik Terhadap Kinerja Karyawan. Journal Of Business Studies, ISSN: 2443-3837.

Ina ratnamiasih, \& warenih. (2014). Pengaruh Kepemimpinan Transformasional dan Transaksional pada Kinerja Pegawai Bappeda Kota Bandung. Jurnal Trikonomika, 119-126.

Irawan, M. S. (2017). Pengaruh Gaya Kepemipinan, Motivasi Intrinsik, Dan Motivasi Ekstrinsik Terhadap Kinerja Karyawan Pada PT. Sukses Bersama Yatfuari (Sby) Gresik-Surabaya. Simki-Economic.

Jannah, N. W., \& Endratno, H. (2017). Pengaruh Motivasi Intrinsik, Motivasi Ekstrinsik, Lingkungan Kerja dan Budaya Organisasi Terhadap Kinerja Karyawan Rumah Sakit Islam Banjarnegara. Jurnal Manajemen dan Bisnis MEDIA EKONOMI.

Karmita, S. B., Suprapta, I. G., \& Priatini, P. S. (2015). Pengaruh Motivasi Kerja Dan Penempatan Karyawan Terhadap Kepuasan Kerja dan Kinerja Karyawan. E-Jurnal Ekonomi dan Bisnis Universitas Udayana, ISSN : 2337-3067.

Aqmarina, N. S. (2016). Pengaruh Kepemimpinan Transaksional Terhadap Kinerja Karyawan Melalui Kepuasan Kerja. Jurnal Administrasi dan Bisnis, 164-173.

Budianto, Ferdinand, \& Sambung, R. (2013). Pengaruh Motivasi Intrinsik dan Motivasi Ekstrinsik Terhadap Kinerja Pegawai Melalui Kepuasan Kerja. Jurnal Sains Manajemen, ISSN : 2302-1411. 
Ghozali, I. (2012). Aplikasi Analisis Multivariate dengan Program SPSS 19. Semarang: Badan Penerbit Universitas Diponegoro.

Guritno, B., \& Prabowo, H. (2016). Analisis Pengaruh Motivasi Intrinsik Terhadap Kepuasan Kerja Yang Berdampak Pada Kinerja Karyawan Di PT. Jhons GF Semarang. Buletin Bisnis \& Manajemen, ISSN: 2442-885X.

Hillaliyyah, N. (2016). Pengaruh Kepemimpinan Transaksional Terhadap Kinerja Karyawan. Management Analysis Journal, ISSN 2252-6552.

Ihsan, A. n. (2017). Pengaruh Kepemimpinan Transaksional Dan Motivasi Intrinsik Terhadap Kinerja Karyawan. Journal Of Business Studies, ISSN: 2443-3837.

Ina ratnamiasih, \& warenih. (2014). Pengaruh Kepemimpinan Transformasional dan Transaksional pada Kinerja Pegawai Bappeda Kota Bandung. Jurnal Trikonomika, 119-126.

Irawan, M. S. (2017). Pengaruh Gaya Kepemipinan, Motivasi Intrinsik, Dan Motivasi Ekstrinsik Terhadap Kinerja Karyawan Pada PT. Sukses Bersama Yatfuari (Sby) Gresik-Surabaya. Simki-Economic.

Jannah, N. W., \& Endratno, H. (2017). Pengaruh Motivasi Intrinsik, Motivasi Ekstrinsik, Lingkungan Kerja dan Budaya Organisasi Terhadap Kinerja Karyawan Rumah Sakit Islam Banjarnegara. Jurnal Manajemen dan Bisnis MEDIA EKONOMI.

Karmita, S. B., Suprapta, I. G., \& Priatini, P. S. (2015). Pengaruh Motivasi Kerja Dan Penempatan Karyawan Terhadap Kepuasan Kerja dan Kinerja Karyawan. E-Jurnal Ekonomi dan Bisnis Universitas Udayana, ISSN : 2337-3067.

Katim, C. (2016). Pengaruh Gaya Kepemimpinan Transaksional Dan Motivasi Terhadap Kinerja Karyawan (Studi Pada Merlynn Park Hotel). Jurnal Riset Manajemen dan Bisnis, 177 -182.

Linawati. (2014). Pengaruh Motivasi Kerja Intrinsik dan Motivasi Kerja Ekstrinsik Terhadap Kinerja Karyawan. Jurnal Ekonomi dan Bisnis, 81-89.

Martunis, E. (2016). Pengaruh Kompensasi Dan Motivasi Kerja Terhadap Kinerja Karyawan Pada PT. Devina Surabaya. Jurnal Ilmu dan Riset Manajemen, ISSN : 2461-0593.

Permana, I. S., Sedjati, R. S., \& Kusniasih, N. (2017). Pengaruh Faktor Motivasi Intrinsik Dan Ekstrinsik Terhadap Kinerja Perawat Di Rsud 45 Kabupaten Kuningan. Jurnal Ekonomi, ISSN: 2302-7169.

Pradana, T. (2016). Pengaruh Gaya Kepemimpinan Transaksional Dan Budaya Organisasi Terhadap Kinerja Karyawan. Jurnal Ilmu dan Riset Manajemen, ISSN : 2461-0593.

Pratama, M. Y. (2017). Pengaruh Motivasi Instrisik Terhadap Kinerja Perawat. E-Jurnal Manajemen Unud, ISSN : 2302-8912.

Rianda, I. R. (2015). Pengaruh Motivasi Instrisik Terhadap Kinerja Karyawan Melalui Kepuasan Kerja. Jurnal Ekonomi dan Bisnis.

Sari, S. P. (2014). Pengaruh Kepemimpinan Transaksional Terhadap Kinerja Karyawan Melalui Kepuasan Kerja. Jurnal Ultima Accounting, 43-58.

Sariningtyas, E. W. (2016). Analisis Karakteristik Individu Dan Motivasi Intrinsik Terhadap Komitmen Organisasi Dengan Kepuasan Kerja Sebagai Variabel Intervening (Studi pada PDAM Tirta Mulia Kabupaten Pemalang). Jurnal Ilmiah UNTAG Semarang, ISSN : 2302-2752. 
Setiaji, N. (2016). Pengaruh Kepemimpinan Transaksional Terhadap Kinerja Karyawan Melalui Kepuasan Kerja. Jurnal Bisnis dan Pembangunan, ISSN 2541-178X.

Setiaji, N. (2016). Pengaruh Kepemimpinan Transaksional Terhadap Kinerja Karyawan Melalui Kepuasan Kerja. Jurnal Bisnis dan Pembangunan.

Setiawan, E. Y. (2015). Pengaruh Gaya Kepemimpinan Transformasional Dan Transaksional Terhadap Kinerja Karyawan PT. ISS Indonesia Di Rumah Sakit National Surabaya. $e$ Jurnal Ilmu Manajemen MAGISTRA, E-ISSN : 2442-4315.

Tatilu, J., Lenkong, V. P., \& Sendow, G. M. (2014). Kepemimpinan Transaksional, Transformasional, Servant Leadership Pengaruhnya Terhadap Kinerja Karyawan Pada PT. Sinar Galesong Pratama Manado. Jurnal EMBA, 295-304.

Taufiq, A. (2016). Pengaruh Motivasi Instrisik Terhadap Kinerja Karyawan Melalui Kepuasan Kerja. Jurnal JBTI, 158-178.

Utami, A. S., \& Suana, I. W. (2015). Pengaruh Kepemimpinan Transaksional Dan Stres Kerja Terhadap Kepuasan Kerjakaryawan Pada PT. PLN (PERSERO) Area Bali Selatan. E-Jurnal Manajemen Unud, ISSN : 2302-8912.

Waruwu, F. (2017). Analisis Tentang Pengaruh Motivasi Intrinsik Dan Motivasi Ekstrinsik Terhadap Kinerja Karyawan. Jurnal Manajemen Maranatha, ISSN 1411-9293.

Yasin, M., Haryono, A. T., \& Paramita, P. D. (2016). The Influence Of Intrinsic Motivationand Entrinsic Motivation, Against The Employee Performance, With Satisfaction To Labor As Variable Intervening. Journal Of Management. 